\title{
Influence of non-puddled transplanting and residues of previous mustard on rice (Oryza sativa L.)
}

Mohammad Mobarak Hossain*1, Mahfuza Begum², Md. Moshiur Rahman², Abul Hashem³, Richard W. Bell ${ }^{4}$, Enamul Haque ${ }^{4}$

\begin{abstract}
On-farm research was conducted at Gouripur sub-district under Mymensingh district of Bangladesh during the boro (mid November-June) season in 2013-14 and 2014-15 to evaluate the performance of non-puddled rice cultivation with and without crop residue retention. The rice var. BRRI dhan 28 was transplanted by two tillage practices viz., puddled conventional tillage (CT) and non-puddled strip tillage (ST) and at two levels of mustard residues, i.e., no residue $\left(\mathrm{R}_{0}\right)$ and $50 \%$ residue $\left(\mathrm{R}_{50}\right)$. The experiment was designed in a randomized complete block design with four replications. There were no significant yield differences between tillage practices and residue levels in 2013-14. But in the following year, ST yielded $9 \%$ more grain compared to CT leading to $22 \%$ higher BCR. Retention of $50 \%$ residue increased yield by $3 \%$ compared to no-residue, which contributed to $10 \%$ higher benefit-cost ratio (BCR). The ST combined with $50 \%$ residue retention yielded the highest grain yield $\left(5.81 \mathrm{t} \mathrm{ha}^{-1}\right)$ which contributed to produce the highest BCR (1.06).
\end{abstract}

Keywords: crop residues, non-puddled, strip tillage, yield

*Corresponding Author: mm.hossain@ irri.org, Tel: +880 1714782704

${ }^{1}$ Rice Breeding Platform (Breeding for Favorable Environment), International Rice Research Institute, Dhaka 1213, Bangladesh; mm.hossain@irri.org

${ }^{2}$ Department of Agronomy, Bangladesh Agricultural University, Mymensingh 2202, Bangladesh; mzap_27@yahoo.co.uk (MB); rahmanag63@gmail.com (MMR)

${ }^{3}$ Department of Primary Industries and Regional Development, Industry and Economic Development, 75 York Road, Northam 6401 WA; hashemau71@ gmail.com

${ }^{4}$ Agricultural Sciences, Murdoch University, South St, Murdoch WA 6150, Australia; r.bell@ murdoch.edu.au (RB); e.haque@ murdoch.edu.au (EH) 


\section{Introduction}

Most of the rice (Oryza sativa L.) farmers in the Asian continent establish seedlings by transplanting in puddled soil. Lands is prepared by one or two passes in dry condition followed by exposure to the sun for a couple of days. Then after inundation, the final field is prepared by ploughing, cross ploughing and laddering in standing water. However, this traditional puddling method is labour, fuel, time and capital consuming (Islam et al., 2014). Nowadays most of the tillage operations for puddling soil in Bangladesh are done by power tiller which is detrimental to physical soil conditions through destroying soil aggregates, breaking capillary pores, and dispersing the soils (Miah et al., 2002). Moreover, puddling produces a hard setting soil when dry which makes land preparation difficult for the following crops (Islam et al. 2012). Not only that, puddled rice transplanting consumes about $20-40 \%$ of the total water required for raising a crop, and it also promotes the formation of hardpan (Singh et al., 2014). Furthermore, it reduces soil organic carbon which apart from decreasing soil fertility accelerates the losses of irrigation water and damage to the environment (Sayre and Hobbs, 2004). Adoption of minimum tillage and non-puddled transplanting might be an alternative to puddled transplanting to overcome these destructive impacts (Singh et al., 2014). This technology has potential to allow saving in labour, energy, water and time during rice establishment as well as improving soil fertility (Islam et al., 2012). Concerning the soil health, another agronomic option is the retaining the residues of previously cultivated crops for their effects on soil physical, chemical and biological functions as well as water and soil quality and on crop yield (Kumar and Goh, 2000). Residue retention maintains soil micro-organisms and microbial activity which can also lead to weed suppression by the biological agents leading to increase crop yield (Shrivastav et al., 2015). Considerable research work was done on puddled transplanting, but there is limited information on non-puddled rice transplanting with crop residue retention under Bangladesh conditions (Haque et al. 2016; Haque and Bell, 2019). Therefore, the present study was conducted to examine the performance of rice using non-puddled transplanting system with the retention of mustard residues.

\section{Materials and Methods}

The experiment had conducted on a farmer's field of Durbachara, Gouripur, Mymensingh, Bangladesh (the latitude of $24.75^{\circ} \mathrm{N}$ and the longitude of $90.50^{\circ} \mathrm{E}$ ) (Fig. 1) during the boro (mid November-June) season in 2013-14 and 2014-15. This experimental area belongs to the Old Brahmaputra Floodplain, which is characterized by dark grey non-calcareous 
alluvium soils belong to the Sonatala series. Soil characteristics are presented in Table 1. Climatic (rainfall and thermal condition) data were collected from the nearest weather station and illustrated in Fig. 2. The treatments were: (i) puddled soil condition following conventional tillage (CT) and (ii) non-puddled soil condition using strip tillage (ST) and; two levels of mustard residues viz., no-residue $\left(\mathrm{R}_{0}\right)$ and $50 \%$ residue $\left(\mathrm{R}_{50}\right)$. The treatments was laid out in randomized complete block design with four replications using unit plots of $9 \mathrm{~m} \times 5 \mathrm{~m}$. In tillage practice, CT consisted of two passes of primary rotary tillage by twowheeler tractor (2 WT) and exposure to the sun for two days followed by inundation of the whole plot and puddling by $2 \mathrm{WT}$ with two passes to complete land preparation. The ST was done by a Versatile Multi-crop Planter (Haque et al., 2016) in a single pass operation before flooding the field. Three days before ST, pre-plant glyphosate herbicide was applied @ 75 $\mathrm{ml} 10 \mathrm{~L}^{-1}$ water. After ST, the land had inundated with $3-5 \mathrm{~cm}$ standing water for one day before transplanting to allow the disturbed strip to soft enough to transplant seedlings (Islam et al., 2014). Thirty-five day-old seedlings of rice var. BRRI dhan 28 were transplanted. Fertilizers have applied according to the recommendation of BRRI (2014). A spacing of 25 $\mathrm{cm} \times 15 \mathrm{~cm}$ was maintained for both CT and ST with 2 or 3 seedlings hill ${ }^{-1}$. The crops were harvested at maturity from $3 \mathrm{~m} \times 3 \mathrm{~m}$ in each plot, and then data were recorded. Grain yield was adjusted to $14 \%$ moisture content. Data were subjected to two-way ANOVA using STAR software and means were separated by Duncan's Multiple Range Test (Gomez and Gomez, 1984).

Table 1: The morphological, physical and chemical properties of soil $(0-15 \mathrm{~cm})$ of the experimental field

A. Morphological characteristics

i. Soil Tract

ii. Soil Series

iii. Parent materials

B. Physical characteristics of soil

i. Sand $(2.00-0.50 \mathrm{~mm}) \quad: \quad 25.2 \%$

ii. Silt $(0.5-0.002 \mathrm{~mm}) \quad: \quad 72.0 \%$

iii. Clay $(<0.002 \mathrm{~mm}) \quad: \quad 2.8 \%$

iv. Textural class : Silty loam

C. Chemical characteristics of soil

i. $\mathrm{pH}: 6.71$

ii. Organic matter $(\%) \quad: 0.93$

iii. Total nitrogen $(\%) \quad: 0.13$

iv. Available sulphur $\left(\mathrm{mg} \mathrm{kg}^{-1}\right) \quad: \quad 13.9$

v. Available phosphorus $\left(\mathrm{mg} \mathrm{kg}^{-1}\right) \quad: \quad 16.3$

vi. Exchangeable potassium $\left(\mathrm{mg} \mathrm{kg}^{-1}\right) \quad: \quad 0.28$ 


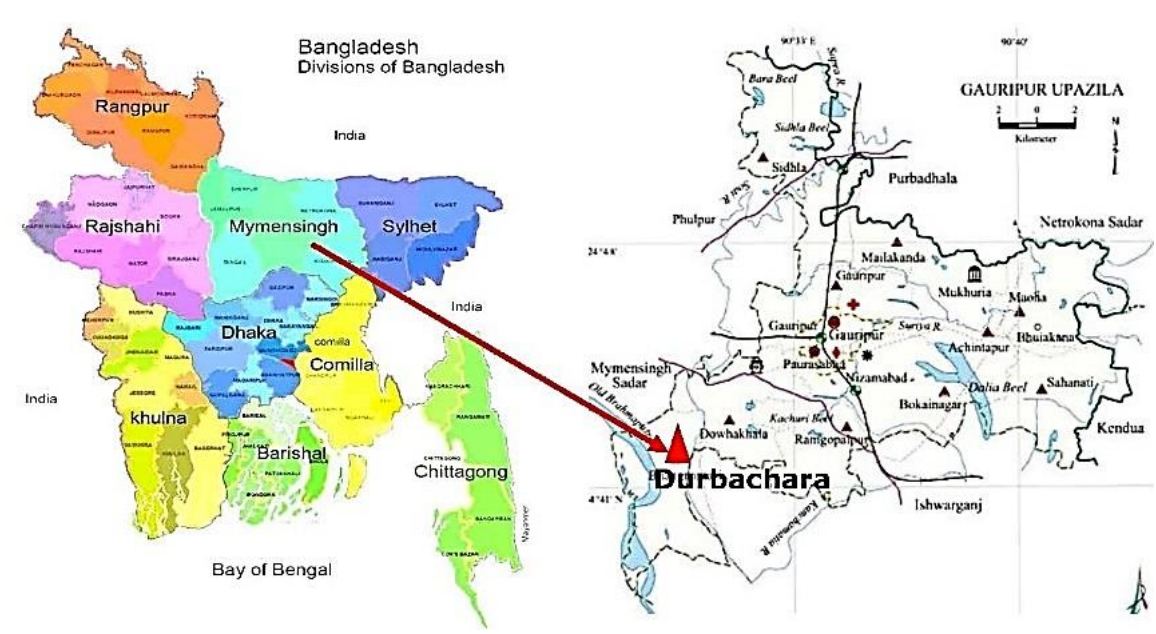

Figure 1. Map of Bangladesh showing the site of on-farm experiment

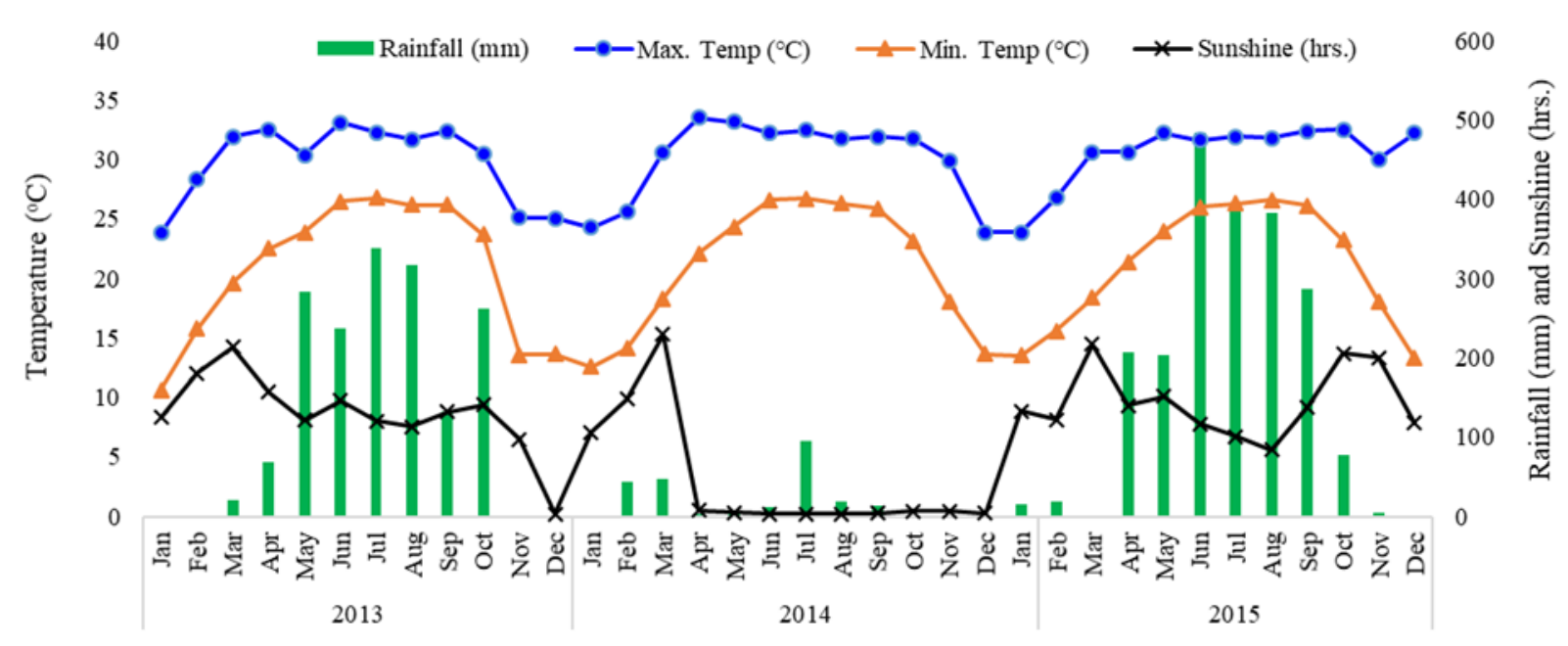

Figure 2. Monthly average temperature, total rainfall, relative humidity and sunshine hours of the experimental site in 2013-2015

\section{Results}

Combined effect of tillage practice and residue levels on yield attributes, yield and the benefit-cost ratio (BCR) of rice

Combination of tillage practice and residue levels exerted significant $(\mathrm{p} \leq 0.05)$ effect only on BCR while the rest of the parameters did not vary significantly ( $p>0.05$ ) during 2013-14. Whereas in 2014-15, a combination of treatments had a significant impact on all the parameters except plant height, panicle length, number of sterile spikelets panicle ${ }^{-1}$ and weight of thousand grain (Table 2). Strip tillage plus 50\% residue retained produced the highest BCR which largely resulted from the highest grain yield. The highest grain yield might be attributed to the highest number of effective tillers $\mathrm{m}^{-2}$ and grains panicle ${ }^{-1}$, and the lowest numbers of non-effective 
tillers $\mathrm{m}^{-2}$. CT or ST with 50\% residue yielded the higher values of these parameters compared to no-residues. CT without residue produced the lowest grain yield and BCR. Compared to CT and no-resdue, ST and 50\% residue increased the grain yield and BCR by $9 \%$ and $22 \%$, and $3 \%$ and $10 \%$, respectively.

Table 2. Combined effect of tillage practice and residue levels on yield contributing characters and yield of rice

\begin{tabular}{|c|c|c|c|c|c|c|c|c|c|c|}
\hline $\begin{array}{l}\text { Tillage } \\
\text { practice }\end{array}$ & $\begin{array}{c}\text { Residue } \\
\text { levels }\end{array}$ & $\begin{array}{l}\text { Plant } \\
\text { height } \\
(\mathrm{cm})\end{array}$ & $\begin{array}{l}\text { No. of } \\
\text { effective } \\
\text { tillers } \\
\mathrm{m}^{-2}\end{array}$ & $\begin{array}{l}\text { No. of non- } \\
\text { effective } \\
\text { tillers } \\
\mathrm{m}^{-2}\end{array}$ & $\begin{array}{c}\text { Panicle } \\
\text { length } \\
(\mathrm{cm})\end{array}$ & $\begin{array}{c}\text { No. of } \\
\text { grains } \\
\text { panicle }^{-1}\end{array}$ & $\begin{array}{c}\text { No. of } \\
\text { sterile } \\
\text { spikelets } \\
\text { panicle }^{-1}\end{array}$ & $\begin{array}{c}1000 \\
\text { grain } \\
\text { weight } \\
\text { (gm) }\end{array}$ & $\begin{array}{l}\text { Grain } \\
\text { yield } \\
\left(\mathrm{t} \mathrm{ha}^{-1}\right)\end{array}$ & $\begin{array}{c}\text { Benefit- } \\
\text { Cost } \\
\text { Ratio }\end{array}$ \\
\hline \multicolumn{11}{|l|}{ 2013-14 } \\
\hline \multirow{2}{*}{$\mathrm{CT}$} & $\mathrm{R}_{0}$ & 109.3 & 207 & 45 & 24.2 & 162 & 53 & 29.5 & 5.21 & $0.73 b$ \\
\hline & $\mathrm{R}_{50}$ & 111.5 & 211 & 43 & 24.6 & 158 & 54 & 29.2 & 5.19 & $0.71 b$ \\
\hline \multirow{2}{*}{ ST } & $\mathrm{R}_{0}$ & 110.8 & 209 & 43 & 24.6 & 158 & 53 & 29.8 & 5.20 & $0.80 \mathrm{a}$ \\
\hline & $\mathrm{R}_{50}$ & 109.1 & 207 & 44 & 24.5 & 160 & 55 & 30.3 & 5.20 & $0.88 \mathrm{a}$ \\
\hline $\operatorname{LSD}_{(0.05)}$ & & NS & NS & NS & $\mathrm{NS}$ & NS & $\mathrm{NS}$ & NS & NS & 0.18 \\
\hline $\mathrm{CV}(\%)$ & & 2.74 & 12.67 & 11.71 & 2.40 & 3.47 & 2.27 & 1.32 & 0.34 & 4.72 \\
\hline \multicolumn{11}{|l|}{ 2014-15 } \\
\hline \multirow{2}{*}{ CT } & $\mathrm{R}_{0}$ & 108.3 & $359 \mathrm{c}$ & $84 a$ & 24.3 & $100 \mathrm{c}$ & 41 & 21.6 & $5.17 \mathrm{~d}$ & $0.78 \mathrm{bc}$ \\
\hline & $\mathrm{R}_{50}$ & 106.3 & $363 c$ & $70 \mathrm{~b}$ & 24.5 & $121 b$ & 39 & 22.2 & $5.29 \mathrm{c}$ & $0.83 \mathrm{c}$ \\
\hline \multirow{2}{*}{ ST } & $\mathrm{R}_{0}$ & 104.2 & $376 b$ & $53 c$ & 24.4 & $129 a b$ & 41 & 22.9 & $5.60 \mathrm{~b}$ & $0.92 b$ \\
\hline & $\mathrm{R}_{50}$ & 106.3 & $388 \mathrm{a}$ & $41 d$ & 24.2 & $139 a$ & 40 & 23.0 & $5.81 \mathrm{a}$ & $1.06 \mathrm{a}$ \\
\hline $\operatorname{LSD}_{(0.05)}$ & & NS & 6.50 & 4.25 & $\mathrm{NS}$ & 11.72 & $\mathrm{NS}$ & NS & 0.13 & 0.045 \\
\hline $\mathrm{CV}(\%)$ & & 4.60 & 1.20 & 5.68 & 3.84 & 5.14 & 8.88 & 6.83 & 2.10 & 1.24 \\
\hline
\end{tabular}

\section{Discussion}

\section{Effect on the yield of rice}

The higher yield in ST might have attributed to the changes in soil properties viz. the higher porosity and better soil moisture conservation in ST favoured the more robust root growth and nutrient uptake resulted in increasing grain yield. These benefits however were evident in the second year but not in first year suggesting that they require at least a year to develop. These results agree Huang et al. (2012) who stated that minimum tillage (MT) non-puddled condition provides more favourable soil physical environment for better crop growth than CT. Pittelkow et al. (2015) and Qi et al. (2011) also reported that higher and more stable crop yields in MT than CT. In CT, heavy smearing of the sub-surface soil by rotary tillage forms a hardpan. Loss of structure, soil degradation and disruption of the soil pores are likely to hamper root growth especially in Rabi season (winter) crop.

On the other hand, crop yield increase in MT might have occurred from the improved soil structure and stability. They may facilitate better water holding capacity and drainage that reduces the extremes of water logging and drought (Holland, 2004), ultimately improving soil 
fertility by sequestering organic carbon in farmland soils (Alam et al., 2019). This finding supports the research result of Liu et al. (2010) who found 20\% higher maize yield in MT than CT due to increase of soil organic carbon, soil total nitrogen and soil total phosphorus by 25 , 18 and 7\%, respectively. These results have implications for understanding how conservation tillage practices increase crop yield by improving soil quality and sustainability in non-puddled strip tillage practices as also reported by Hossain et al. (2016) and Mvumi et al. (2017). Some research findings also concluded no yield differences between ST and CT. Haque et al. (2016) found the similar grain yield of rice in non-puddled ST transplanting and CT, which confirms the earlier findings of Hossain et al. (2015) who also found no yield penalty of wheat and rice between ST and CT. In another study, Sharma et al. (2011) also reported similar rice yield in non-puddled transplanting to the CT. Wiatrak et al. (2005) found identical cotton yield in ST and CT while Al-Kaisi and Licht (2004) found the similar corn and soybean yield in ST, NT and CT. The finding of these studies confirms the result of the present study where no significant yield loss was found in the first year of the experiment.

In this study, retention of $50 \%$ of mustard residues increased the grain yield of rice by about 120-210 kg ha ${ }^{-1}$ over no-residue. Research finding of Shrivastav et al. (2015) confirm that standing residue converts to mineralized nutrients which causes sufficient crop growth and facilitates higher yield over no-residue. Kaschuk et al. (2010) and Qin et al. (2010) concluded straw residue retention directly increases the input of organic matter and nutrients into the soil, in turn improving soil nutrient availability for crop growth and better yield over no-residue. The earlier study of Thomas et al. (2007) and Govaerts et al. (2007) also found the benefits of residue retention on crop yield. Improved soil fertility and water availability might occur from the supplies of organic matter from straw residue for heterotrophic $\mathrm{N}$ fixing micro-organisms, which could increase nitrozen supply to the crops. Straw residues for controlling weeds in different crops have suggested by Devasinghe et al. (2011), and Hossain et al. (2016) concluded residues restrict weed growth and thus retards crop-weed competition.

\section{Effect on the benefit-cost ratio (BCR) of rice}

Partial economic analysis disclosed that among the treatments ST with 50\% residue earned the highest profit. Variation in BCR might have attributed to the variation in grain yield and cost required for rice cultivation. One hectare of land preparation in CT required US\$190.80 while ST required US\$ 35.80. Thus, ST saved around 68\% of the cost for land preparation. This estimation is in line with Haque et al. (2016) estimating 70\% savings in land preparation in ST over CT since the lowest land preparation cost was recorded in ST (US\$ $32.54 \mathrm{ha}^{-1}$ ) while the 
higher land preparation cost was incurred in CT (US\$110.29 ha-1). Islam et al. (2014) estimated $49 \%$ savings from land preparation in ST over CT. Savings in ST might attributed to the fewer tillage passes and lower fuel consumption for land preparation than in CT. In addition to that, ST reduced fuel and labour requirements during land preparation. About 10\% higher profit after retaining 50\% residue might have occurred solely from $3 \%$ higher grain yield than noresidue. Therefore, the two year study confirmed that rice cultivation through practising nonpuddled strip tillage with the retention of 50\% crop residue could achieve a higher profit compared to existing conventional tillage of rice cultivation in both years and higher yield in the second year of the experiment.

\section{Conclusion}

Based on this two-year study, we can conclude that non-puddled rice transplanting with the retention of crop residues was a profitable alternative to existing conventional tillage operation and farmers are likely to be benefited by increased profit through adopting this practice.

\section{Acknowledgements}

This study was a part of PhD research work which was funded by the Australian Centre for International Agricultural Research (ACIAR).

\section{References}

Al-Kaisi M, Licht A. 2004. Effect of strip tillage on corn nitrogen uptake and residual soil nitrate accumulation compared with no-tillage and chisel plow. Agronomy Journal 96, 1164-1171. DOI: org/10.2134/agronj2004.1164

Alam MK, Bell RW and Biswas WK 2019. Increases in soil sequestered carbon under conservation agriculture cropping decrease the estimated greenhouse gas emissions of wetland rice using life cycle assessment. Journal of Cleaner Production 224, 72-87. 2019. DOI: org/10.1016/j.jclepro.2019.03.21.

BRRI (Bangladesh Rice Research Institute). 2014. Modern Rice Cultivation. The $16^{\text {th }}$ edition. BRRI, Joydebpur, Gazipur-1701, Bangladesh. p. 5-28.

Devasinghe D, Premarathne KP, Sangakkara UR. 2011. Weed management by rice straw mulching in direct seeded lowland rice (Oryza sativa L.). Tropical Agricultural Research 22(3), 263 - 272. DOI: org/10.4038/tar.v22i3.3699 
Gomez KA, Gomez AA. 1984. Statistical Procedure for Agricultural Research. The $2^{\text {nd }}$ edition. John Wiley \& Sons. Inc., New York. p. 680.

Govaerts B, Fuentes M, Mezzalama M, Nicol JM, Deckers J, Etchevers JD, Figueroa SB, Sayre KD. 2007. Infiltration, soil moisture, root rot and nematode populations after 12 years of different tillage, residue and crop rotation managements. Soil and Tillage Research 94, 209-219. DOI: org/10.1016/j.still.2006.07.013

Haque ME, Bell RW. 2019. Non-puddled rice performance in on-farm demonstrations. Plant Production Science 22, 23-45. DOI: 10.1080/1343943X.2018.1564335

Haque ME, Bell RW, Islam MA, Rahman MA. 2016. Minimum tillage non-puddled transplanting: an alternative crop establishment strategy for rice in conservation agriculture cropping systems. Field Crops Research 185, 31-39. DOI: org/10.1016/j.fcr.2015.10.018

Holland JM. 2004. The environmental consequences of adopting conservation tillage in Europe: reviewing the evidence. Agriculture, Ecosystems and Environment 103(1), 125. DOI: org/10.1016/j.agee.2003.12.018

Hossain MI, Sarker MJU, Haque MA. 2015. Status of conservation agriculture-based tillage technology for crop production in Bangladesh. Bangladesh Journal of Agricultural Research 40(2), 235-248. DOI: org/10.3329/bjar.v40i2.24561

Hossain MM, Begum M, Rahman MM, Hashem A. 2016. Response of T. Aman and Boro rice to residue retention under strip tillage. Bangladesh Agronomy Journal 18(2), 39-44. DOI: org/10.3329/baj.v18i2.28902

Huang G, Chai Q, Feng F, Yu A. 2012. Effects of different tillage systems on soil properties, root growth, grain yield and water use efficiency of winter wheat (Triticum aestivum L.) in Arid Northwest China. Journal of Integrative Agriculture 11(8), 1286-1296. DOI: org/10.1016/S2095-3119(12)60125-7

Islam AKMS, Hossain MM, Saleque MA, Rahman MA, Karmakar B, Haque ME. 2012. Effect of minimum tillage on soil properties, crop growth and yield of aman rice in drought prone northwest Bangladesh. Bangladesh Agronomy Journal 15(1), 43-51.

Islam AKMS, Hossain MM, Saleque MA. 2014. Effect of non-puddled transplanting on the growth and yield of dry season rice (Oryza sativa L.) in High Barind Tract. The Agriculturists 12(2), 91-97. DOI: org/10.3329/agric.v12i2.21736

Kaschuk G, Alberton O, Hungria M. 2010. Three decades of soil microbial biomass studies in Brazilian ecosystems: lessons learned about soil quality and indications for improving 
sustainability. Soil Biology and Biochemistry 42, 1-13. DOI: org/10.1016/j.soilbio.2009.08.020

Kumar K, Goh KM. 2000. Crop residues and management practices: effects on soil quality, soil nitrogen dynamics, crop yield and nitrogen recovery. Advances in Agronomy 68, 198-279. DOI: org/10.1016/S0065-2113(08)60846-9

Liu EK, Zhao BQ, Mei XR, So HB, Li J, Li XY. 2010. Effects of no-tillage management on soil biochemical characteristics in northern China. The Journal of Agricultural Science 148(2), 217-223. DOI: org/10.1017/S0021859609990463

Miah MAM, Islam MS, Miah MTH. 2002. Socio-economic impacts of farm mechanization on the livelihoods of rural labourers in Bangladesh. Journal of Farm Economics 12, 147162.

Mvumi C, Ndoro O, Manyiwo SA. 2017. Conservation agriculture, conservation farming and conventional tillage adoption, efficiency and economic benefits in semi-arid Zimbabwe. African Journal of Agricultural Research 12(19), 1629-1638. DOI: org/10.5897/AJAR2017.12153

Pittelkow CM, Liang X, Linquist BA, Van Groenigen KJ, Lee J, Lundy ME, van Gestel N, Six J, Venterea RT, van Kessel C. 2015. Productivity limits and potentials of the principles of conservation agriculture. Nature 517, 365-368. DOI: org/10.1038/nature13809

Qi YB, Huang B, Darilek JL. 2011. Impacts of agricultural land management on soil quality after 24 years: a case study in Zhangjiagang County, China. New Zealand Journal of Agricultural Research 54(4), 261-273. DOI: org/10.1080/00288233.2011.604678

Qin SP, He XH, Hu CS, Zhang YM, Dong WX. 2010: Responses of soil chemical and microbial indicators to conservational tillage versus traditional tillage in the North China Plain. European Journal of Soil Biology 46, 243-247. DOI: org/10.1016/j.ejsobi.2010.04.006

Sayre KD, Hobbs P. 2004. The raised-bed system of cultivation for irrigated production conditions. In: Lal R, Hobbs PR, Norman U, Hansen DO Eds. Sustainable agriculture and the intonational rice-wheat system, CRC Press, p. 337-355. DOI: org/10.1201/9780203026472.ch20

Sharma P, Abrol V, Sharma RK. 2011. Impact of tillage and mulch management on economics, energy requirement and crop performance in maize-wheat rotation in rainfed sub humid Inceptisols, India. European Journal of Agronomy 34, 46-51. DOI: org/10.1016/j.eja.2010.10.003 
Shrivastav N, Basnet KB, Amgain LP, Karki TB, Khatri N. 2015. Weed dynamics and productivity of spring maize under different tillage and weed management methods. Azarian Journal of Agriculture 2(5), 118-122.

Singh A, Kumar R, Kang JS. 2014. Tillage system, crop residues and nitrogen to improve the productivity of direct seeded rice and transplanted rice. Current Agriculture Research Journal 2(1), 14-29. DOI: org/10.12944/CARJ.2.1.03

Thomas GA, Titmarsh GW, Freebairn DM, Radford BJ. 2007. No-tillage and conservation farming practices in grain growing areas of Queensland-a review of 40 years of development. Australian Journal of Experimental Agriculture, 47 887-898. DOI: org/10.1071/EA06204

Wiatrak PJ, Wright DL, Marois JJ. 2005. Evaluation of strip tillage on weed control, plant morphology, and yield of glyphosate-resistant cotton. The Journal of Cotton Science 9, 10-14.

Zheng C, Jiang Y, Chen C, Sun Y, Feng J, Deng A, Song Z, Zhang W. 2014. The impacts of conservation agriculture on crop yield in China depend on specific practices, crops and cropping regions. The Crop Journal 2(5), 289-296. DOI: org/10.1016/j.cj.2014.06.006 